\title{
Antitumor Activity of Leaves from Hyptis mutabilis (A. Rich.) Briq. (Lamiaceae) in Mice Bearing Tumor
}

\author{
Rafael Matos Ximenes, ${ }^{1,2}$ Antônio Mario Melo, ${ }^{1}$ Lucimeri Paulino Machado Magalhães,' \\ Ivone Antonia de Souza, ${ }^{1}$ and Julianna Ferreira Cavalcanti de Albuquerque ${ }^{1}$ \\ ${ }^{1}$ Department of Antibiotics, Federal University of Pernambuco, 50670-091 Recife, PE, Brazil \\ ${ }^{2}$ Department of Physiology and Pharmacology, Federal University of Ceará, 60430-270 Fortaleza, CE, Brazil
}

Correspondence should be addressed to Julianna Ferreira Cavalcanti de Albuquerque; albuquerquejfc@gmail.com

Received 27 March 2012; Accepted 11 April 2012

Academic Editors: S. Kishioka and E. Küpeli Akkol

Copyright (C) 2013 Rafael Matos Ximenes et al. This is an open access article distributed under the Creative Commons Attribution License, which permits unrestricted use, distribution, and reproduction in any medium, provided the original work is properly cited.

\begin{abstract}
The Hyptis genus has more than 400 species, many of them being used in folk medicine to treat several conditions. Some anticancer compounds have been isolated from plants of this genus, and for that reason we decided to investigate the potential in vivo antitumor activity of extracts of leaves of Hyptis mutabilis with different polarities (hexane, methanol, water, and hot water) against two mice tumors: sarcoma 180 and Ehrlich solid tumor. Phytochemical analysis revealed strong presence of steroids, saponins, flavonoids (mainly dihydroflavanols), and catechins. Acute toxicity was perfomed according to the up-and-down method showing $\mathrm{LD}_{50}$ values ranging from 100 up to $2500 \mathrm{mg} / \mathrm{kg}$. Antitumor activity was investigated using $10 \%$ of the $\mathrm{LD}_{50}$ for each extract. Methotrexate was used as positive control. Both aqueous extracts showed strong inhibition of tumor growth with values up to $70 \%$ of inhibition growth for sarcoma 180. Ehrlich solid tumor was only slight inhibited by hexane extract (38.6\%). In conclusion, the aqueous extracts of $H$. mutabilis showed promising results against sarcoma 180 mice tumor.
\end{abstract}

\section{Introduction}

The genus Hyptis (Lamiaceae) has more than 400 species distributed in tropical regions of Americas and Africa [1-3]. Several species of this genus are aromatic and used in folk medicine to treat digestives disorders, pain, gastrointestinal problems, and skin infections [4]. Many pharmacological properties of the genus Hyptis have been reported: that is, antimicrobial $[5,6]$, antiulcer and gastroprotective [7], larvicidal [8], antidepressant [9], and anti-inflammatory and antinociceptive [10,11].

From the phytochemical point of view, the genus has been extensively studied: terpenoids, including monoterpenes and sesquiterpenes present in essential oil, flavonoids, lactones, lignans, and alkaloids were isolated and identified [12]. The anticancer agents $3^{\prime}$-demethyldesoxypodophyllotoxin and betulinic acid were isolated from plants of this genus [13]. Based on these findings, we evaluated the antitumor activity of Hyptis mutabilis (A. Rich.) Briq. against murine tumors in these work.

\section{Methodology}

Male Swiss mice $(20-25 \mathrm{~g})$ were obtained from the animal facilities of the Department of Antibiotics of the Federal University of Pernambuco. All animals were kept under standard conditions, with temperature at $25 \pm 2^{\circ} \mathrm{C}, 12 \mathrm{~h}$ light/dark cycle, and relative humidity, with food and water ad libitum. Experiments were carried out in accordance with the ethical principles of The Brazilian College of Animal Experiments and the National Institute of Health Guide for Care and Use of Laboratory Animals. This study was previously approved by the Committee of Experimental Animals of the Federal University of Pernambuco (004788/2005-68).

Plant material and extract were as follows. Leaves from H. mutabilis were collected in Aldeia (Camaragibe-PE). Botanical identification was made by Professor Dr. Alda Andrade Chiappeta of the Department of Antibiotics, Federal University of Pernambuco. Voucher specimen was deposited at the Herbarium of the Department of Antibiotics (DAUFPE 6256). Leaves were dried in open air at room temperature 
$\left(28 \pm 2^{\circ} \mathrm{C}\right)$ and crushed with an electric grinder. Powdered leaves $(940 \mathrm{~g})$ were subjected to serial extractions with increasing polarity solvents: hexane, methanol, water, and hot water. The sample was extracted three times with each solvent ( 3 hours each under stirring), filtered, and subjected to the next extraction. Hexane and methanol extracts were evaporated under low pressure at constant temperature of $45^{\circ} \mathrm{C}$, yielding $17.64 \mathrm{~g}(1.88 \%)$ and $61.42 \mathrm{~g}$ $(6.53 \%)$, respectively. Water extracts were liophilized yielding $44.01 \mathrm{~g}(4.68 \%)$ for water and $22.00 \mathrm{~g}(2.34 \%)$ for hot water.

For the phytochemical analysis we performed phytochemical screening according to Matos [14] and Sena Filho et al. [15], based on chemical tests, to detect the presence of common secondary metabolite classes, mainly alkaloids, terpenes, and phenolic compounds, in hexane and methanolic extracts, using classical specific colour reactions.

Acute toxicity was evaluated according to the up-anddown method to determine $\mathrm{LD}_{50}$ values using fewer animals as possible (described in OECD 425).

Antitumor activity against Ehrlich solid tumor and sarcoma 180 was investigated. Ehrlich ascite carcinoma and sarcoma 180 were maintained in vivo in mice by transplantation of $0.2 \mathrm{~mL}$ of ascitic fluid $\left(1 \times 10^{7}\right.$ cells $)$ from the infected mice to the noninfected mice [16]. The Ehrlich ascites or sarcoma 180 ascites $(\mathrm{S} 180)$ tumor cells $\left(1 \times 10^{7}\right.$ cells/mouse) were subcutaneously implanted into the inguinal region of the mice as described by Sugiura and Stock [17]. Mice were divided into the respective groups and the treatment started after 24 hours of tumor cells' implantation.

For the treatment of each tumor group, animals $(n=6)$ were divided in six groups: negative control (received 1\% DMSO dissolved in saline solution $0.9 \%$, i.p.), positive control (received $10 \mathrm{mg} / \mathrm{kg}$ of methotrexate, i.p.), and four groups treated with $\mathrm{H}$. mutabilis extracts $\left(10 \%\right.$ of $\mathrm{LD}_{50}$ found for each extract). Hexane extract group were treated with $250 \mathrm{mg} / \mathrm{kg}$ (i.p.), methanol extract group received $230 \mathrm{mg} / \mathrm{kg}$ (i.p.), and water and hot water extracts received $150 \mathrm{mg} / \mathrm{kg}$ and $10 \mathrm{mg} / \mathrm{kg}$, respectively, both intraperitoneally to avoid food-extract interactions. Animals were treated once a day during seven days. On the eighth day, mice were weighed and killed and the tumors were removed. The inhibition of tumor growth was calculated by percentage of reduction of the tumors when compared with the negative control group.

\section{Dataset Description}

The dataset associated with this Dataset Paper consists of 3 items which are described as follows.

Dataset Item 1 (Table). Phytochemical screening of methanolic and hexanic extracts of $H$. mutabilis leaves revealed the presence mainly of steroids, saponins, flavonoids (mainly dihydroflavonols), and catechins. In the table, "+" means weak; "++", medium; "+++", strong; and " 0 ", absent. These results are similar to those found for other Hyptis species [12].

\section{Column 1: Secondary Metabolites Classes \\ Column 2: Methanolic Extracts \\ Column 3: Hexanic Extracts}

Dataset Item 2 (Table). $\mathrm{LD}_{50}$ values obtained for H. mutabilis extracts according to OECD 425 protocol. Single-dose acute toxicity tested showed values of $L D_{50}$ ranging from $100 \mathrm{mg} / \mathrm{kg}$ to $2500 \mathrm{mg} / \mathrm{kg}$. The dose used to test the antitumor activity of the extracts was $10 \%$ of the $\mathrm{LD}_{50}$; at these doses, no histological changes were observed in mice treated for seven days. So, these doses were considered safe for use in the following in vivo experiments [18].

\section{Column 1: Extract}

Column 2: $\mathrm{LD}_{50}\left(\mathrm{mg} \mathrm{kg}^{-1}\right)$

Dataset Item 3 (Table). In vivo growth inhibition percentual of sarcoma 180 (S180) and Ehrlich solid tumor (EST) of H. mutabilis extracts. Significant reduction of sarcoma 180 tumor mass was obtained with water extracts $(72.4$ and $74.3 \%$ of inhibition of tumor growth for water and hot water extracts, resp.) after 7 days of treatment. Methotrexate was used as standard drug, used as positive control, and completely inhibited sarcoma 180 tumor growth. Hexane and methanol extracts just slightly inhibit sarcoma 180 growth. Ehrlich solid tumor was only inhibited by hexane extract (38.6\% of inhibition), while methotrexate inhibited 98.2\% of tumor growth. Data were expressed as mean \pm S.E.M. No difference in the weight of the animals was observed among the tested groups. These results were obtained after 7 days of treatment, during which the animals were monitored for the appearance of adverse reactions, common to major commercial anticancer drugs. In the mice treated with $H$. mutabilis extracts, no strong adverse effects were observed, while in methotrexate groups, animals presented behavioral changes and enterocolitis. In the table, "-” indicates no inhibition.

$$
\begin{aligned}
& \text { Column 1: Group } \\
& \text { Column 2: Dose, i.p. }\left(\mathrm{mg} \mathrm{kg}^{-1}\right) \\
& \text { Column 3: S180 Inhibition (\%) } \\
& \text { Column 4: EST Inhibition (\%) }
\end{aligned}
$$

\section{Concluding Remarks}

Plants are rich source of antitumor agents and many of the antitumor drugs in the market are derived from them [1921]. Both water and hot water extracts of $H$. mutabilis showed promising antitumor activity against sarcoma 180 murine tumor. These data point to the presence of polar compounds present in these extracts that are probably responsible for this activity. As no adverse effect or any histopathological changes were observed during the 7 days of treatment, these data will serve to put forward other research groups to make a phytochemistry approach to isolate polar compounds in others to characterize the polar active compounds present 
in this plant. Hexane extract showed a slight inhibition of Ehrlich solid tumor probably due to nonpolar compounds that were not tested in phytochemical screening, such as carotenoids and fatty acids.

\section{Dataset Availability}

The dataset associated with this Dataset Paper is dedicated to the public domain using the CC0 waiver and is available at http://dx.doi.org/10.7167/2013/169357/dataset.

\section{Conflict of Interests}

The authors have no conflict of interests to disclose.

\section{Acknowledgments}

The authors wish to thank CNPq (National Council for Research) for financial support and Sidney Ann Pratt for language revision.

\section{References}

[1] A. I. R. Luz, M. G. B. Zoghbi, L. S. Ramos, J. G. S. Maia, and M. L. Da Silva, "Essential oils of some amazonian labiatae, 1. Genus Hyptis," Journal of Natural Products, vol. 47, no. 4, pp. 745-747, 1984.

[2] R. B. Porter, P. B. Reese, L. A. Williams, and D. J. Williams, "Acaricidal and insecticidal activities of cadina-4,10 (15)-dien3-one," Phytochemistry, vol. 40, no. 3, pp. 735-738, 1995.

[3] K. Pålsson and T. G. T. Jaenson, "Plant products used as mosquito repellents in Guinea Bissau, West Africa," Acta Tropica, vol. 72, no. 1, pp. 39-52, 1999.

[4] S. M. Morai, J. D. P. Dantas, A. R. A. Silva, and E. F. Magalhães, "Plantas medicinais usadas pelos índios Tapebas do Ceará," Revista Brasileira de Farmacognosia, vol. 15, no. 2, pp. 169-177, 2005.

[5] L. K. H. Souza, C. M. A. De Oliveira, P. H. Ferri et al., "Antimicrobial activity of Hyptis ovalifolia towards dermatophytes," Memorias do Instituto Oswaldo Cruz, vol. 98, no. 7, pp. 963-965, 2003.

[6] C. M. A. De Oliveira, M. D. R. R. Silva, L. Kato, C. C. Da Silva, H. D. Ferreira, and L. K. H. Souza, "Chemical composition and antifungal activity of the essential oil of Hyptis ovalifolia Benth. (Lamiaceae)," Journal of the Brazilian Chemical Society, vol. 15, no. 5, pp. 756-759, 2004.

[7] P. P. P. Barbosa and C. P. Ramos, "Studies on the antiulcerogenic activity of the essential oil of Hyptis mutabilis Briq. in rats," Phytotherapy Research, vol. 6, no. 2, pp. 114-115, 1992.

[8] J. G. M. Costa, F. F. G. Rodrigues, E. C. Angélico et al., "Estudo químico-biológico dos óleos essenciais de Hyptis martiusii, Lippia sidoides e Syzigium aromaticum frente às larvas do Aedes aegypti," Revista Brasileira de Farmacognosia, vol. 15, no. 4, pp. 304-309, 2005.

[9] A. X. Bueno, A. T. S. Moreira, F. T. Silva, C. S. Estevam, and M. Marchioro, "Effects of the aqueous extract from Hyptis pectinata leaves on rodent central nervous system," Brazilian Journal of Pharmacognosis, vol. 16, no. 3, pp. 317-323, 2006.

[10] M. D. Bispo, R. H. V. Mourão, E. M. Franzotti et al., "Antinociceptive and antiedematogenic effects of the aqueous extract of Hyptis pectinata leaves in experimental animals," Journal of Ethnopharmacology, vol. 76, no. 1, pp. 81-86, 2001.

[11] H. S. Falcão, I. O. Lima, V. L. Santos et al., "Review of the plants with anti-inflammatory activity studied in Brazil," Brazilian Journal of Pharmacognosis, vol. 15, no. 4, pp. 381-391, 2005.

[12] D. Q. Falcão and F. S. Menezes, "The Hyptis genus: na ethopharmacological and chemical review," Brazilian Journal of Pharmacy, vol. 84, no. 3, pp. 69-74, 2003.

[13] D. G. I. Kingston, M. M. Rao, and W. Y. Zucker, "Plant anticancer agents. IX. Constituents of Hyptis tomentosa," Journal of Natural Products, vol. 42, no. 5, pp. 496-499, 1979.

[14] F. J. A. Matos, Introdução a Fitoquímica Experimental, UFC, Fortaleza, Brazil, 2nd edition, 1997.

[15] J. G. Sena Filho, J. G. S. Melo, A. M. Saraiva, A. M. Gonçalves, M. N. C. Psiottano, and H. S. Xavier, "Antimicrobial activity and phytochemical profile from the roots of Lippia alba (Mill.) N.E. Brown," Brazilian Journal of Pharmacognosy, vol. 16, no. 4, pp. 506-509, 2006.

[16] A. P. A. D. Gurgel, J. G. da Silva, A. R. S. Grangeiro et al., "In vivo study of the anti-inflammatory and antitumor activities of leaves from Plectranthus amboinicus (Lour.) Spreng (Lamiaceae)," Journal of Ethnopharmacology, vol. 125, no. 2, pp. 361-363, 2009.

[17] K. Sugiura and C. C. Stock, "Studies in a tumor spectrum. III. The effect of phosphoramides on the," Cancer Research, vol. 15, no. 1, pp. 38-51, 1955.

[18] D. B. Vendramini-Costa, I. B. D. D. Castro, A. L. T. G. Ruiz, C. Marquissolo, R. A. Pilli, and J. E. D. Carvalho, "Effect of goniothalamin on the development of Ehrlich solid tumor in mice," Bioorganic and Medicinal Chemistry, vol. 18, no. 18, pp. 6742-6747, 2010.

[19] I. Lampronti, M. T. H. Khan, N. Bianchi et al., "Plants with antitumor properties: from biologically active molecules to drugs," Advances in Phytomedicine, vol. 2, pp. 45-63, 2006.

[20] L. Pan, H. Chai, and A. D. Kinghorn, "The continuing search for antitumor agents from higher plants," Phytochemical Letters, vol. 3, no. 1, pp. 1-8, 2010.

[21] D. J. Newman and G. M. Cragg, "Natural products as sources of new drugs over the last 25 years," Journal of Natural Products, vol. 70, no. 3, pp. 461-477, 2007. 

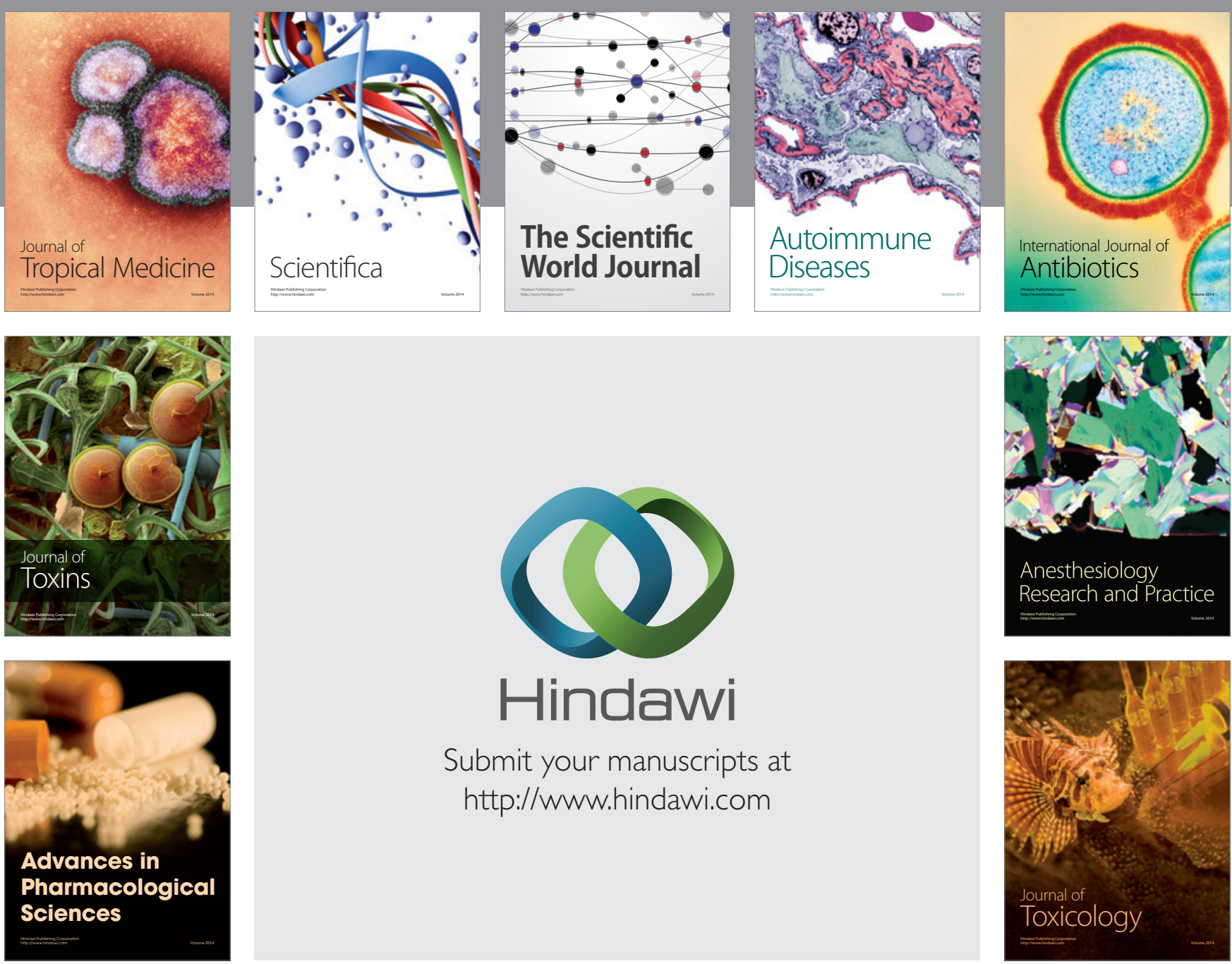

\section{Hindawi}

Submit your manuscripts at

http://www.hindawi.com
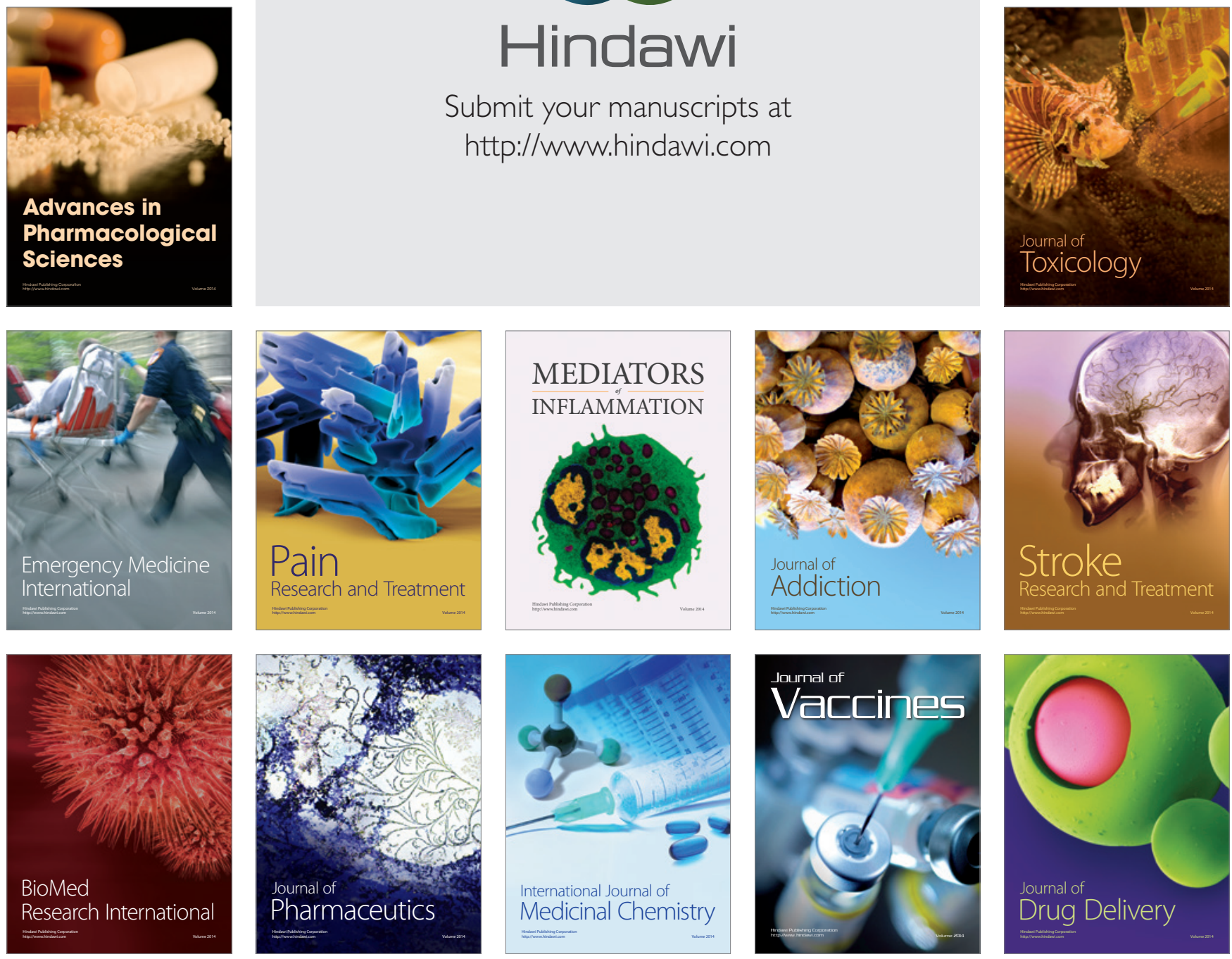